\title{
Relationship between drug interactions and drug-related negative clinical outcomes
}

\author{
Javier CREMADES, Mario GONZALO, Isabel ARREBOLA. \\ Received (first version): 23-Jan-2008 Accepted: 5-Feb-2009
}

\begin{abstract}
${ }^{*}$
Drug interactions may represent an iatrogenic risk that should be controlled in community pharmacies at the dispensing level.

Aim: We analyzed the association between potential drug-drug interactions (DDIs) and negative clinical outcomes.

Methods: We used dispensing data from two community pharmacies: instances where drug dispensing was associated with a potential DDI and a comparison group of randomized dispensing operations with no potential DDI. In cases where potential DDIs were detected, we analyzed the underlying negative clinical outcomes. Age and gender data were included in the analysis.

Results: During the study period, we registered 417 potential DDIs. The proportion of women and age were higher in the study group than in the comparison group. The average potential DDIs per patient was 1.31 (SD=0.72). The Consejo General de Colegios Oficiales de Farmacéuticos (CGCOF) database did not produce an alert in $2.4 \%$ of the cases. Over-the-counter medication use was observed in $5 \%$ of the potential DDI cases. The drugs most frequently involved in potential DDIs were acenocoumarol, calcium salts,

hydrochlorothiazide, and alendronic acid, whereas the most predominant potential DDIs were calcium salts and bisphosphonates, oral antidiabetics and thiazide diuretics, antidiabetics and glucose, and oral anticoagulant and paracetamol. The existence of a drug-related negative clinical outcome was observed only in $0.96 \%$ of the potential DDI cases (50\% safety cases and $50 \%$ effectiveness cases). Conclusions: Only a small proportion of the detected potential DDIs lead to medication negative outcomes. Considering the drug-related negative clinical outcomes encountered, tighter control would be recommended in potential DDIs with NSAIDs or benzodiazepines.
\end{abstract}

Keywords: Drug Interactions. Community Pharmacy Services. Spain.

\footnotetext{
*Javier CREMADES. PhD. Community Pharmacists at Aspe, Alicante (Spain).

Mario GONZALO. BScPharm. Community Pharmacist at Crevillente, Alicante (Spain).

Isabel ARREBOLA. BScPharm. Community Pharmacists at Aspe, Alicante (Spain).
}

\author{
RELACIÓN ENTRE INTERACCIONES \\ MEDICAMENTOSAS Y RESULTADOS \\ CLÍNICOS NEGATIVOS DE LA \\ MEDICACIÓN
}

\section{RESUMEN}

Las interacciones medicamentosas pueden representar un riesgo iatrogénico que debería controlarse en las farmacias comunitarias durante la dispensación.

Objetivo: Analizamos la asociación entre interacciones medicamentosas potenciales (DDI) y resultados clínicos negativos.

Métodos: Utilizamos los datos de dispensación de dos farmacias comunitarias: cuando el medicamento dispensado se asociaba a una DDI potencial y un grupo de comparación de dispensaciones aleatorizadas sin DDI potencial. En los casos en que se detectaba DDI potencial, se analizaron los subsiguientes resultados clínicos negativos. Los datos de edad y sexo se incluyeron en el análisis.

Resultados: Durante el periodo de estudio registramos 417 DDI potenciales. La proporción de mujeres y la edad era mayor en el grupo de estudio que en el de comparación. La media de DDI potenciales por paciente fue de $1,31(\mathrm{DE}=0,72)$. $\mathrm{La}$ base de datos del Consejo General de Colegios Oficiales de Farmacéuticos (CGCOF) no produjo ninguna alerta en el 2,4\% de los casos. Se observó el uso de medicamentos OTC en el 5\% de las DDI potenciales. Los medicamentos más frecuentemente involucrados en DDI potenciales fueron acenocumarol, sales de calcio, hidroclorotiazida y ácido alendrónico, mientras que las DDI potenciales más frecuentes fueron de sales de calcio con bisfosfonatos, de antidiabéticos orales con diuréticos tiazídicos, de antidiabéticos con glucosa, y de anticoagulantes orales con paracetamol. Se observó existencia de resutados clínicos negativos de la medicación en sólo el $0,96 \%$ de las DDI potenciales $(50 \%$ por inefectividad y $50 \%$ por inseguridad).

Conclusiones: Sólo una pequeña proporción de DDI potenciales detectadas condujeron a resultados negativos de la medicación. Considerando los resultados clínicos negativos encontrados, debería realizarse un control más estrecho de las DDI potenciales con AINE o benzodiacepinas.

Palabras clave: Interacciones medicamentosas. Servicios de farmacias comunitarias. España. 


\section{INTRODUCTION}

A drug interaction is defined as the alteration of the effect of one drug by the presence of another. The number of drug interactions increases with to the number of drugs used. Because increased life expectancy is accompanied by an increase in medication use, this field of pharmacotherapy is an important public health issue.,

The incidence of drug interactions is a controversial issue. Study results vary greatly because of population type and methodology. Apart from this complexity, we must distinguish between potential drug-drug interactions (potential DDI) and drug-drug interactions that actually occur. ${ }^{2}$

The frequency of potentially dangerous interactions in ambulatory patients is genuinely low. ${ }^{3,4}$ However, if we take into account the large number of drugs that are prescribed and dispensed on a daily basis, a considerable number of patients can potentially be at risk. ${ }^{2}$ Even though few cases of serious interactions occur, the suspected iatrogenic risks must be considered and controlled. ${ }^{4,5}$ Accordingly, an important percentage of hospital admissions caused by medication can be attributed to drug interactions. $^{6-11}$

The European Council's resolution about the pharmacist's role within the health security framework establishes that verifying the appropriateness in the prescription and the possible interactions is a desirable practice. ${ }^{12}$ In this context, the community pharmacy is in a privileged position to detect these phenomena because medical prescriptions from different physicians, dental prescriptions, and self-medication converge in the pharmacy. ${ }^{13}$ In Spain, one study ${ }^{14}$ shows that only $6 \%$ of pharmacies detected a relevant drug-drug interaction, while studies undertaken in the USA ${ }^{15}$ present higher values (32\%).

Most pharmacies in Spain are computerized. Pharmacy management software includes a Consejo General de Colegios Oficiales de Farmacéuticos (CGCOF) database that allows the automatic detection of potential DDls between dispensed drugs. Although useful, the low specificity of drug interaction detection means that the attention paid to the alerts issued by these computer systems is lost. ${ }^{4,16}$ Systematically overriding potential DDIs via configuring the alert systems can be distinguished from overriding potential DDIs generated by computer alerts without further action. ${ }^{18}$

The identification of a potential DDI does not necessarily lead to a negative outcome, as it involves characteristics of the patient, the drugs, and the use of the drugs. ${ }^{19}$ Several works have studied drug interactions and have also analyzed them according to clinical relevance. ${ }^{1,3,4}$

We analyzed the prevalence of potential DDIs detected in community pharmacies during dispensing and the relationship with negative clinical outcomes.

\section{METHODS}

The potential DDls in connection with negative clinical outcomes were analyzed in two community pharmacies in the province of Alicante (Spain), one located in Aspe (inland) and the other based in El Campello (coastal). Both pharmacies had similar characteristics in terms of personnel and the origin of prescriptions. The study was carried out over a six-month period from June to December, 2005.

The dispensing operations data were registered according to two groups. One group (the study group) was formed by dispensing operations in which a potential DDI was detected. The second group (the comparison group) included randomized dispensing operations in which no potential DDI was detected.

Dispensing was done using commercial management software that included the CGCOF database (Spanish Pharmacists Association). This software produces an alert for potential drug interactions. The pharmacist was called by the technician when a potential DDI alert appeared. Then, the pharmacist completed the process. Potential DDIs detected by the pharmacist that were not included in this database were also registered.

All negative outcomes were classified according to the Third Consensus of Granada on Drug-related Problems and Negative Outcomes Associated with Medication. $^{20}$

In the study group, we acted in accordance with a decision algorithm after detecting a potential DDI (Figure 1). The first criterion used in this protocol was to look at the likelihood of seeing the negative clinical outcome. The drug administration route was considered, as were the doses, and whether it involved a novel drug or they had been taken together for a long time. The case was recorded if it was considered that no negative outcome would appear.

If there was a possibility that a negative clinical outcome would appear, we then asked the patient for possible clinical signs and symptoms. If no sign was detected, when considered relevant we informed the patient to return to the community pharmacy should these signs ever appear. Conversely, when negative clinical outcome signs were detected, we offered the patient pharmacotherapy follow-up.

If a serious potential DDI was detected (defined as that which would likely require an urgent change in therapy), dispensing was suspended according to the information taken from the patient. This information had to fit at least one of two assumptions: that the physician did not know the use of all the drugs involved, and that it was the first time that the patient used one of the drugs. In both cases the patient was advised to refer back to his/her physician, and the case was excluded. 


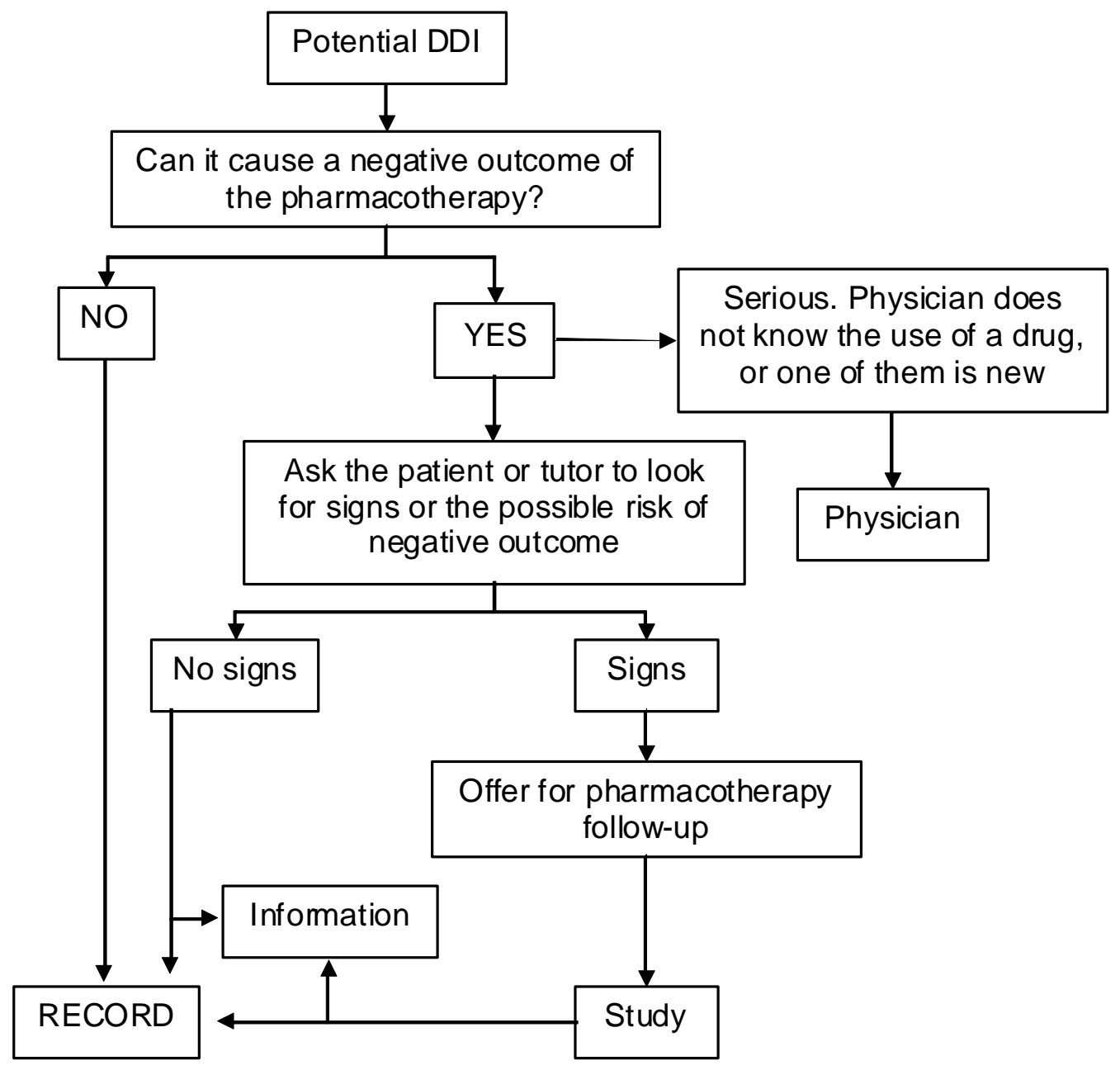

Figure 1: Decision algorithm after detecting an interaction

The following data were registered in the study group: the potential DDI; the patient's name, age, and gender; the drugs involved and whether these drugs were prescribed; the possible negative clinical outcome; the detection of a drug-related negative clinical outcome; and any information given either to the patient or physician. In the comparison group, age and gender were also registered and expressed as the mean value and standard error (SE). The ages of both groups were compared using the Student's t-test. Gender differences were evaluated between the two groups using the chi-square test. The level of statistical relevance used in both analyses was $p<0.05$. The rest of the data are expressed as the mean value and standard deviation (SD).

\section{RESULTS}

During this study, 39,340 dispensing operations were performed, and 417 potential DDIs were detected $(1.06 \%$ of dispenses lead to a potential DDI). These 417 potential DDIs were detected in 318 dispensing operations (see Table 1). The mean rate of the potential DDIs per dispensing was 1.31 $(S D=0.72$ range 1 to 5$)$. Only one $(n=254$ dispensing acts; $79.9 \%$ ) or two ( $\mathrm{n}=43$ dispensing acts; $13.5 \%$ ) potential DDIs were detected in the majority of cases. However, there were cases of three $(n=11 ; 3.4 \%)$, four $(n=7 ; 2.3 \%)$, and five $(n=3$ dispensing acts; $0.9 \%$ ) potential DDls registered for the same dispensing act.

\begin{tabular}{|l|c|c|c|}
\hline \multicolumn{4}{|c|}{ Table 1: Characteristics of study and control groups. } \\
\hline & $\begin{array}{c}\text { Potential } \\
\text { DDI group }\end{array}$ & $\begin{array}{c}\text { Control } \\
\text { group }\end{array}$ & $\mathrm{p}$ value \\
\hline $\begin{array}{l}\text { Number of potential } \\
\text { DDIs detected }\end{array}$ & 417 & - & - \\
\hline $\begin{array}{l}\text { Number of } \\
\text { dispensing } \\
\text { operations }\end{array}$ & 318 & 417 & - \\
\hline Age (years) \pm SE & $59.8 \pm 0.9$ & $51.3 \pm 1.1$ & $\mathrm{p}<0.001$ \\
\hline Sex & $\begin{array}{c}204 \text { women } \\
114 \text { men }\end{array}$ & $\begin{array}{c}233 \text { women } \\
184 \text { men }\end{array}$ & $\mathrm{p}<0.050$ \\
\hline
\end{tabular}

The mean age of patients with potential DDIs was $59.8(\mathrm{SE}=0.9)$ years old, and it was $51.3(\mathrm{SE}=1.1)$ years old for dispensing without potential DDIs $(p<0.001)$. Gender registration data were also significantly different between both groups, with a high rate of women in the potential DDI group (204 women of 318 dispensing acts vs. 233 women of 417 dispensing acts in the comparison group; $\mathrm{p}<0.05)$. 
Pharmacists found $10(2.4 \%)$ potential DDls not appearing in the computerized alert system, despite being described in either the literature, the summary of product characteristics of the drugs involved, or in the drug description in the database.

Active substances and excipients involved in the vast majority of potential DDI cases appear in Table 2. The most frequently detected potential DDIs are presented in Table 3.

In $21(5 \%)$ potential DDIs, a dispensed drug that was not prescribed by a physician but could be obtained over the counter was detected.

Only $4(0.96 \%)$ potential DDls led to a negative clinical outcome $(50 \%$ safety and $50 \%$ effectiveness cases). These negative outcomes involved NSAIDs in two cases and benzodiazepines in another two; $22 \%$ and $9 \%$ of the potential DDIs with NSAID and benzodiazepine, respectively, led to a negative clinical outcome.

\begin{tabular}{|l|c|c|}
\hline \multicolumn{3}{|l|}{ Table 2: Main drugs or excipients involved in } \\
potential DDIs. \\
\hline \multicolumn{1}{|c|}{ Drug or excipient } & $\mathrm{n}$ & $\%$ \\
\hline Acenocoumarol & 72 & 8.6 \\
\hline Calcium salts & 51 & 6.1 \\
\hline Hydrochlorothiazide & 38 & 4.6 \\
\hline Alendronic acid & 35 & 4.2 \\
\hline Metformin & 34 & 4.1 \\
\hline Omeprazol & 32 & 3.8 \\
\hline Paracetamol & 28 & 3.4 \\
\hline Digoxin & 20 & 2.4 \\
\hline Sucrose & 20 & 2.4 \\
\hline Glibenclamide & 20 & 2.4 \\
\hline Simvastatin & 19 & 2.3 \\
\hline Amiodarone & 17 & 2.0 \\
\hline Insulin & 17 & 2.0 \\
\hline Ibuprofen & 15 & 1.8 \\
\hline Propranolol & 15 & 1.8 \\
\hline Risendronic Acid & 14 & 1.7 \\
\hline Acetylsalicylic acid & 13 & 1.6 \\
\hline Carbamazepine & 11 & 1.3 \\
\hline Clorazepate & 11 & 1.3 \\
\hline Enalapril & 9 & 1.1 \\
\hline Espironolactone & 9 & 1.1 \\
\hline Allopurinol & 8 & 1.0 \\
\hline Atenolol & 8 & 1.0 \\
\hline Captopril & 8 & 1.0 \\
\hline Furosemide & 8 & 1.0 \\
\hline Torasemide & 8 & 1.0 \\
\hline Metrotexate & 8 & 1.0 \\
\hline Other & 286 & 34 \\
\hline & & \\
\hline
\end{tabular}

In $23.2 \%$ of the detected potential DDI cases, the patient was directly informed about the drug interaction. This information was given to the physician in only $1 \%$ of cases.

\section{DISCUSSION}

We tested potential DDIs in connection with negative clinical outcomes in two Spanish community pharmacies. NSAIDs or benzodiazepines appeared in all potential DDIs that had negative clinical outcomes, suggesting acting with caution in potential DDls where these drugs appear.
The frequency of potential DDIs in dispensing $(1.06 \%)$ is generally lower than other studies, with prevalence from 0.8 to $80 \%$. $^{1,4,21-23}$ However, different methodologies, the potential DDIs considered, the study population, the year of the study, and inclusion of non-prescription drugs can all affect these values. For example, we only considered medications identified during a specific dispensing, and did not consider the patient's medication history. DDIs must be identified to be prevented, and experience (measured as years of pharmacy training) improved the accuracy identifying potential DDls. ${ }^{24}$ Alert systems are also effective in community pharmacies and in physician offices in reducing the number of potential DDIs. ${ }^{25}$ Nevertheless, these systems are not a panacea $a^{5,10,15,18,26}$, and require optimization of alerts $^{18,26}$ and access to complete medication history.

The age of patients with potential DDIs was significantly higher than the group where no potential DDI was detected, consistent with other studies where the number of potential DDIs increased with the patient age $\mathrm{e}^{1,27}$, as do the number of drugs used. ${ }^{27}$ We also found a higher proportion of women in the group with potential DDIs. Other studies found similar gender-related differences, suggesting that perhaps women take more medication than men, and also live longer. ${ }^{28}$ Importantly, the most frequent interaction found, bisphosphonate and calcium salts, is generally used to treat osteoporosis in postmenopausal women.

The average number of potential DDIs per patient of $1.31(\mathrm{SD}=0.72)$ was similar to that described by other authors in ambulatory patients ${ }^{29}$, but was slightly lower than in hospitalized patients. ${ }^{30}$ In this sense, Kohler et al. ${ }^{31}$ found that the number of interactions per patient was higher during hospitalization than prior to it.

Drugs usually involved in potential DDls included some drugs frequently used in primary care, such as omeprazole or paracetamol. Other potential DDIs involved drugs that are normally used together, like calcium salts and alendronic acid. This could cause overlap in findings of other studies. For example, of the 24 drugs that caused $60 \%$ of potential DDIs, only 6 in this study were not indicated among the drugs that caused $84 \%$ of potential DDIs in Barris et al. $^{19}$

In $5 \%$ of potential DDI cases, one of the drugs did not require a prescription. Strong control of potential DDIs involves the pharmacist because they might be the only health worker to evaluate the risks. In the work of Barris et al. ${ }^{19}$, these potential DDIs constituted one of the main causes of pharmaceutical intervention. These facts show the importance of a specific pharmaceutical indication and/or active dispensing of medication without a prescription.

The common potential DDIs in this study were similar to the potential DDIs found by other authors. ${ }^{13,18,19,22}$

In this study, the pharmacists detected that $0.94 \%$ of the potential DDIs led to a negative outcome in 
pharmacotherapy. Potential DDls are a source of adverse drug events. ${ }^{7-11}$ NSAIDs and benzodiazepines were both involved in two drugrelated negative clinical outcomes. A considerable percentage of potential DDIs with NSAID and benzodiazepine $(22 \%$ and $9 \%$, respectively) led to a negative clinical outcome. Therefore, tighter control of such cases is recommended. NSAIDs are more involved in clinically relevant pharmacological interactions. $^{3,11}$

Of the interactions with a negative clinical outcome, zolpidem and diazepam did not appear in the CGCOF database, although this interaction appeared in the Summary of Product Characteristics of Stilnox (zolpidem). Nine other potential DDls were not registered in the CGCOF database. Abarca et al. ${ }^{26}$ suggested that the performance of community pharmacy computer systems in screening potential DDIs has improved. Nevertheless, many pharmacy computer systems may be operating at low levels of sensitivity and specificity when screening for DDIs. Databases often have significant omissions and should be dynamically updated. ${ }^{32}$ Moreover, one of the ten non-registered potential DDIs led to a negative outcome, indicating the importance of both the database alerts and other combinations of drugs that may cause a potential DDI, such as combining drugs with similar or opposite effects.

\begin{tabular}{|l|c|c|c|}
\hline \multicolumn{1}{|c|}{ Table 3: Main potential DDIs detected and potential adverse effect associated. } \\
\hline \multicolumn{1}{|c|}{ Potential DDI } & $\mathrm{n}$ & $\%$ & Potential adverse effect \\
\hline Calcium salts + bisphosphonates & 37 & 8.9 & Decreased bisphosphonate effectiveness \\
\hline Oral antidiabetic + thiazide diuretics & 27 & 6.5 & Decreased antidiabetic effectiveness \\
\hline Antidiabetic + glucose & 19 & 4.6 & Decreased antidiabetic effectiveness \\
\hline Oral anticoagulant + paracetamol & 18 & 4.3 & Hemorrhage risk \\
\hline Antidiabetic + ACE Inhibitors & 17 & 4.1 & Hypoglycaemia \\
\hline Benzodiazepines + omeprazol & 14 & 3.4 & Benzodiazepine intoxication risk \\
\hline Oral anticoagulant + HMG-CoA Reductase Inhibitors & 12 & 2.9 & Hemorrhage risk \\
\hline Antidiabetic + beta blockers & 11 & 2.6 & Decreased diabetic control \\
\hline Amiodarone + statins & 9 & 2.2 & Statin intoxication risk \\
\hline Antitussive + mucoltycs & 8 & 1.9 & Risk of stasis of the fluid snot \\
\hline Alendronic acid + NSAID & 8 & 1.9 & Risk of gastric sore \\
\hline Potassium-sparing diuretics + ACE Inhibitors & 7 & 1.7 & Risk of hyperkalemia \\
\hline Paracetamol + oral contraceptive & 6 & 1.4 & Decreased paracetamol effectiveness \\
\hline Oral anticoagulant + amiodarone & 6 & 1.4 & Hemorrhage risk \\
\hline Digitalic + Potassium-sparing diuretics & 6 & 1.4 & Risk of digitalic intoxication \\
\hline Salicylate + antiacid & 6 & 1.4 & Decreased salicylate effectiveness \\
\hline Thiazide diuretic + alopurinol & 6 & 1.4 & Risk of allergic reactions \\
\hline Loop diuretics + NSAID & 5 & 1.2 & Decreased diuretic and antihipertensive \\
\end{tabular}

Some of the drug-related negative clinical outcomes were probably not detected because six patients declined the offer of pharmacotherapy follow-up. Moreover, not detecting a sign when questioning patients does not exclude the possibility of a negative outcome associated with medication. We also only considered drugs identified during dispensing, but patients are probably exposed to a higher number of potential DDIs that could produce negative outcomes.

\section{CONCLUSIONS}

In our study, the majority of potential drug interactions have no clinical relevance, but a small proportion $(0.96 \%)$ lead to negative outcomes. These negative clinical outcomes suggest acting with caution in potential DDIs where NSAIDs or benzodiazepines appear.

\section{ACKNOWLEDGEMENTS}

The authors thank Diego Echevarria, Ph.D. and Juan Miragall, M.Sc. for their critical reading of the manuscript.

\section{CONFLICT OF INTEREST}

None declared.

\section{References}

1. Merlo J, Liedholm H, Lindblad U, Bjorck-Linne A, Falt J, Lindberg G, Melander A. Prescriptions with potential drug interactions dispensed at Swedish pharmacies in January 1999: cross sectional study. BMJ. 2001;323(7310):427-428.

2. Stokley IH. Interacciones farmacológicas. Barcelona: Pharma Editores; 2004.

3. Calvet A, Díez de Ulzurrum, Pérez MT, Esteras J. Interacciones farmacológicas en tratamientos crónicos: medidas correctoras para su prevención en un área básica de salud. Aten Primaria. 2001;27(1):33-37.

4. Peng CC, Glassman PA, Marks IR, Powler C, Castiglione B, Good CB. Retrospective drug utilization review: incidence of clinically relevant potential drug-drug interactions in a large ambulatory population. J Manag Care Pharm. 2003;9(6):513-522. 
5. Becker ML, Kallewaard M, Caspers PW, Schalekamp T, Stricker BH. Potential determinants of drug-drug interaction associated dispensing in community pharmacies. Drug Saf. 2005;28(5):371-378.

6. Manchon ND, Bercoff E, Lemarchand P, Chassagne P, Senant J, Bourreille J. Incidence and severity of drug interactions in the elderly: a prospective study of 639 patients. Rev Med Interne. 1989;10(6):521-525.

7. Huic M, Mucolic V, Vrhovac B, Francetic I, Bakran I, Giljanovic S. Adverse drug reactions resulting in hospital admission. Int J Clin Pharmacol Ther. 1994;32(12):675-682.

8. McDonnell PJ, Jacobs MR. Hospital admissions resulting from preventable adverse drug reactions. Ann Pharmacother. 2002;36(9):1331-1336.

9. Juurlink DN, Mamdani M, Kopp A, Laupacis A, Redelmeier DA. Drug-drug interactions among elderly patients hospitalized for drug toxicity. JAMA. 2003;289(13):1652-1654.

10. Sandson N. Drug-drug interactions: The silent epidemic. Psychiat Serv. 2005;56(1):22-24

11. Becker ML, Kallewaard M, Caspers PW, Visser LE, Leufkens HG, Stricker BH. Hospitalisations and emergency department visits due to drug-drug interactions: a literature review. Pharmacoepidemiol Drug Saf. 2007;16(6):641-651.

12. Resolución ResAP (2001) 2 sobre el papel de los farmacéuticos en el marco de la seguridad sanitaria. Consejo de Europa.

13. Lien LL, Lien EJ. Preventing potential drug interactions in community pharmacie. J Clin Pharm Ther. 1994;19(6):371379.

14. Acosta J, Alzaga A, Álvarez L, Gudiel M, Fernández-Llimos F. Análisis del proceso de dispensación y detección de interacción potencial en farmacias de Alcorcón (Madrid) y Bilbao. Seguim Farmacoter. 2004;2(1):32-36.

15. Cavuto NJ, Woosley RL, Sale M. Pharmacies and prevention of potentially fatal drug interactions. JAMA. 1996;275(14):1086-1087.

16. Westein MP, Herings RM, LeufkensHG, Determinants of pharmacist's interventions linked to prescription processing. Pharm World Sci. 2001;23(3):98-101.

17. Glassman PA, Simon B, Belperio $P$, Lanto A. Improving recognition of drug interactions: benefits and barriers to using automated drug alerts. Med Care. 2002;40(12):1161-1171.

18. Indermitte J, Beutler M, Bruppacher R, Meier CR, Hersberger KE. Management of drug-interaction alerts in community pharmacies. J Clin Pharm Ther. 2007;32(2):133-142.

19. Barris D, Rodríguez C, Sabio B, Garrido B. Interacciones farmacológicas detectadas en una farmacia comunitaria. Pharm Care Esp. 2003;5:261-267.

20. Consensus Committee. Third Consensus of Granada in Drug Related Problems (DRP) and Negative Outcomes associated with Medication (NOM). Ars Pharm. 2007;48(1):5-17.

21. Linnarsson R. Drug interactions in primary health care. A retrospective database study and its implications for the design of a computerized decision support system. Scand J Prim Health Care. 1993;11(3):181-186.

22. Doubova Dubova SV, Reyes-Morales H, Torres-Arreola Ldel P, Suárez-Ortega. Potential drug-drug and drug-disease interactions in prescriptions for ambulatory patients over 50 years of age in family medicine clinics in Mexico City. BMC Health Serv Res. 2007;7:147.

23. Mahmood M, Malone DC, Skrepnek GH, Abarca J, Armstrong EP, Murphy JE, Grizzle AJ, Ko Y, Woosley RL. Potential drug-drug interactions within Veterans Affairs medical centers. Am J Health Syst Pharm. 2007;64(14):1500-1505.

24. Weideman RA, Bernstein IH, McKinney WP. Pharmacist recognition of potential drug interactions. Am J Health Syst Pharm. 1999;56(15):1524-1529.

25. Halkin H, Katzir I, Kurman I, Jan J, Malkin BB. Preventing drug interactions by online prescription screening in communitypharmacies and medical practices. Clin Pharmacol Ther. 2001;69(4):260-265.

26. Abarca J, Colon LR, Wang VS, Malone DC, Murphy JE, Armstrong EP. Evaluation of the performance of drug-drug interaction screening software in community and hospital pharmacies. J Manag Care Pharm. 2006;12(5):383-389.

27. Egger SS, Rätz Bravo AE, Hess L, Schlienger RG, Krähenbühl S. Age-related differences in the prevalence of potential drug-drug interactions in ambulatory dyslipidaemic patients treated with statins. Drugs Aging. 2007;24(5):429-440.

28. Malone DC, Hutchins DS, Haupert H, Hansten P, Duncan B, Van Bergen RC, Solomon SL, Lipton RB. Assessment of potential drug-drug interactions with a prescription claims database. Am J Health Syst Pharm. 2005;62(19):1983-1991.

29. Stephens M, Kukulka G. Frequency of Drug Interactions Among Primary Care Patients at a Family Medicine Residency Clinic. Abstracts 2006 NAPCRG Annual Meeting PS184.

30. López Vázquez P, Rodriguez Moreno C, Duran Parrondo C, Tato Herrero F, Rodríguez López I, Lado Lado FL. Interacciones entre medicamentos prescritos al alta en un servicio de medicina interna. An Med Interna. 2005;22(2):6975.

31. Kohler GI, Bode-Boger SM, Busse R, Hoopmann M, Welte T, Boger RH. Drug-drug interactions in medical patients: effects of in-hospital treatment and relation to multiple drug use. Int J Clin Pharmacol Ther. 2000;38(11):504-513.

32. De Diego A, Alvarellos ML, Del Barrio H. Análisis de la compleción de la base de datos del Consejo General de Colegios Oficiales de Farmacéuticos sobre interacciones entre medicamentos. Pharm Care Esp. 1999;1:184-193. 